International Journal of Instruction e-ISSN: 1308-1470 • www.e-iji.net

Article submission code: 20200821085344

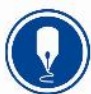

October $2021 \bullet$ Vol.14, No.4

p-ISSN: 1694-609X

pp. 753-774

Received: $21 / 08 / 2020$

Revision: 20/04/2021
Accepted: 16/05/2021

OnlineFirst: 02/09/2021

\title{
Exploration of Moral Integrity Education and Superior Cadre Leadership at Madrasah Boarding School Indonesia
}

Umar

Doctoral student, Universitas Negeri Malang \& Lecturer at Islamic Institute of Muhammadiyah Sinjai, Indonesia, oemar.tech.iaim@gmail.com

\section{Punaji Setyosari}

Prof., Department of Instructional Technology, Faculty of Education, Universitas Negeri Malang, Indonesia, punaji.setyosari.fip@um.ac.id

\section{Waras Kamdi}

Prof., Department of Mechanical Engineering Education, Faculty of Engineering, Universitas Negeri Malang, Indonesia, waras.ft@um.ac.id

\section{Sulton}

Dr., Department of Instructional Technology, Faculty of Education, Universitas Negeri Malang, Indonesia, sulton.fip@um.ac.id

This article uncovers learning methods and teaches moral integrity and leadership in training a six-year cadre. The empirical voicing moral integrity problem affects many people from various countries, including Indonesia. Moreover, moral decadence and value inconsistency are increasing among young potential national leaders, which is urgently noted through moral integrity education and superior human resources at madrasah boarding schools that develop integrative and longlife learning. This has led to many proposals for improving integrity. A qualitative design with a phenomenological approach was used in this research, while the participants' criteria consisted of educators, alumni, national figures, and organizational leaders totaling 25 people. Furthermore, the learning method is developed after the data collection and integrated, leading to the moral integrity internalization of prospective leaders with a superior cadre formation scheme. As a result, the method fosters integrity and leadership in various ways, contributing to the development of leadership talents and moral integrity character in Islamic education programs. Therefore, this helps in adaptation and strengthening characters in other fields, including preventive action, promoting academic integrity success, and valuable to knowledge by educators at large.

Keywords: moral education, integrity, leadership, superior cadres, madrasah boarding school

Citation: Umar., Setyosari, P., Kamdi, W., \& Sulton. (2021). Exploration of moral integrity education and superior cadre leadership at madrasah boarding school Indonesia. International Journal of Instruction, 14(4), 753-774. https://doi.org/10.29333/iji.2021.14443a 


\section{INTRODUCTION}

Indonesia experienced significant changes in cultural life, values, morals, and characters: hence, many people encountered problems, such as injustice and lack of public trust due to unbearable personal integrity in society. As a result, they decided to take shortcuts and work against ethics and rules, leading to Hand-Catching Operation (OTT) on government officials by Corruption Eradication Commission (KPK) officers resulting from dishonesty, transfer of responsibility, and violation of leadership duties. Therefore, education institutions, such as campuses, and government agencies have voiced for "Integrity" zone, while the intervention against the Indonesian nation's Pancasila ideology indicates that integrity in the country is at a decadence stage.

Based on the research, upholding morals, religion, and Pancasila among Indonesians, cannot shun them from neglecting the violation of ethical values, and character (Suyahmo, 2014). Furthermore, it is observed that international problem results from moral crisis and corruption (Lickona, 1993), which has led to various countries, such as Singapore, Germany, Australia, India, and New Zealand to focus on advocating education values (Singh, 2011). Moreover, the authors realized that the empirical contradiction in learning has prioritized practical knowledge and final academic graduation rather than moral values within students in Indonesia's schools. This has led to the younger generation being unfamiliar with integrity, although honesty is an essential value required (Sihombing, 2018). Therefore, if the moral character is not reinforced, the social life of individuals can be greatly affected, for instance, nation disintegration. From this perspective, the educational practice should enforce the foundation of national character, which becomes a reference for the development of educational character.

Indonesia's educational philosophy was conceptualized by Ki Hajar Dewantara as noble character education (Kuswandi, 2009), whose goals are vital in the formulation of the graduate profile, such as high moral integrity, complex problem solving, critical thinking creativity, and capability (Kamdi, 2009). Moreover, the national strategic policy towards strengthening character education has promoted values as a character builder for the past decade. According to Umami et al., (2019); Musschenga, (2001) this concept is urgent and should be prioritized to focus on strengthening motivation, independence, imaginative critical thinking, and promoting moral unity. This helps to solve various problems affecting the integrity of students' academic (Stephens and Wangaard, 2013). Therefore, integrity culture endures students' good academic results, add confidence to the progress of the entire community, provide social skills, and instill a positive impact on professionalism as a basic need, and future wellbeing.

This analysis is based on the integration of moral integrity into character learning, where integrating character education and social skills enhances success in students' academics (Pala, 2011). According to Betawi, (2018) determining the dimensions of moral integrity, such as empathy, honesty, respect, and courage in early childhood increases after the learning program. Furthermore Baharom et al., (2014) suggests that measuring the integrity role provides high performance and impacts Islamic education management through the spiritual, intellectual, social, and material dimensions. Therefore, integrity 
education in schools should be reinforced by the collective role of both parties, and teachers should be comprehensively involved in designing different ways to develop integrity in continuous learning (Nillsen, 2004).

Madrasah in Indonesia are effectively developing character; hence, many people choose them due to their uniqueness in promoting social, emotional, cognitive, psychomotor, moral values, spiritual values, and individual humanism (Hardaker and Sabki, 2015). For instance, Muhammadiyah school develops the internalization of Islamic values education (Raihani, 2012), which makes an essential contribution to the Muslim world (Arif et al., 2017). However, it experiences a negative image that develops radical political views. Furthermore, madrasah and pesantren (Islamic boarding school) in Indonesia provides the same learning values (Fakhruddiana and Sulisworo, 2017), as one of their effort towards promoting humanity amongst their students (Anam et al., 2019). There are also substantial similarities between the madrasah education concept and character education, while the difference lies in theocentric (religion) with a balance of cognitive, affective, and philosophical achievements towards the anthropocentric truth (Supa'at, 2014).

From the previous research, character education in madrasah still focuses on the general value of character, while the pedagogical context of moral integrity and leadership is limited in phenomenological studies. Therefore, this study outlines the six-year learning method in shaping the moral integrity of superior cadres empirically to promote potential leaders. However, there is a gap between educators in cultivating integrity character. This is why the integrity of high school students in Indonesia is classified as good, especially honesty, tolerance, and nationalities, as influenced by the religious environment dimensions (Badruzzaman, 2019).

The research also investigates the moral integrity education among adolescents using shortcuts and do not appreciate the process, though they require high integrity. Therefore, this study contributes to good moral education, which is accompanied by integrity and moral behavior in the educational process. Furthermore, Madrasah Boarding School Muallimin Muhammadiyah Yogyakarta suggests a phenomenological moral character development, hence, this study: (1) Explores and determines the concept of training superior cadres for six years; (2) Identifies learning concepts, which leads to moral integrity formation and; (3) Analyzes the phenomenon of learners' subjective experiences in internalizing moral integrity.

\section{Literatur Review}

\section{The Concept of Moral Integrity Education}

Moral Integrity is essential for humans and thus many experts present diverse perspectives. The term of integrity was used by the dictionary (Hornby, 2010: 781), "meaning wholeness, an overall, unbroken state". Someone with integrity will have harmony in speaking and acting consistently, and have moral grandeur. In psychology, moral integrity is interpreted as undivided, something complete and intact, the union that connects the process of self with others showing quality (Horowitz, 2001). Relevant to the benevolent context proposed Musschenga, (2001) and external consistency, integrity 
also refers to internal coherence and flexibility, such as trustworthiness, values, and behavior. Therefore, integrity can be realized if there is a conformity of commitments, actions, principles of values, morals, norms, and rules to indicate honesty, and honesty becomes the dimension of integrity and the core of character (Becker, 1998, Huberts, 2018). The harmony of moral character and actions shows integrity. According to Mitchell, (2015), a person can act morally if he has moral knowledge and attitude, so he needs the concept of moral education. This definition proposes the notion of integrity as the unity of one's conception of values, morals, and behavior to show self-quality.

According to Dunn, (2009), the definition of integrity is more than just the consistency of moral values, words, behavior, and social values. The study of Erhard et al., (2017) found a new model of integrity with four phenomena: completeness, morals, ethics, and legality. This phenomenon is at two poles of normative and positive values. The aspects of morality, ethics, and legality are in authoritarian policies, and integrity is in the positive realm. Meanwhile, Musschenga, (2002), also illustrated the concept of integrity in global and local formalities. Formal global relations are close to a moral and personal identity so that integrity will appear as an identity, while environmental integrity includes the definition of roles and cases. The concept of Integrity exists in the form of cases, including: (1) Academic honesty moral and plagiarism (Piascik and Brazeau, 2010); (2) Moral integrity in government and organization (Huberts, 2018; Becker, 1998); (3) Integrity in Human Resource management (Noelliste, 2013); (4). Moral integrity in leadership as an essential trait in decision making, (Schuyler, 2010; Gea, 2014; Karthikeyan, 2017). All of them highlight moral integrity as an essential foundation for creating ethical and performance initiatives.

The history of Indonesian education has recorded the concept of Pancasila Moral Education, which leads to the formation of citizens' moral values and national integrity, such as loyalty to the Pancasila and the 1945 Constitution. The concept of character education then becomes an alternative and choice in strengthening the dimensions of children's characters. Values in Islamic education are very relevant to moral integrity that makes children grow into whole human beings who are virtuous and excellent as the behavior of the Prophet Muhammad, namely Siddiq (honest), Amanah (trustworthy), Fatonah (smart), and Tabliq (delivering) (Kusuma, 2011). However, according to Nucci, (2001), the character of children's integrity in modern studies is rarely developed.

Integrity has some dimensions, such as honesty, commitment, consistency, and moral responsibility. According to Lickona, (2004), integrity is significant to be taught in character education policies apart from other values. This character education aims to develop and instill productive potential, commendable habits, leadership and responsibility, independent, insightful, and pleasant school environment for children and adolescents (Kementerian Pendidikan Nasional, 2010). Teachers even teach values to children and adolescents in the United States (Lickona, 1993). Moral education in this second century will strengthen moral integrity and develop productive potential (Zhaoqin, 1998). Furthermore, moral integrity can be taught through the creation of 
teacher competencies, learning environments, school culture, and strengthening moral identity (Wangaard, 2016).

In Indonesia, there are five values of cultural and national character education: religious, nationalist, independent, cooperative, and integrity. Furthermore, there are 18 types of characters derived from ethical values, pancasila, and culture, namely religious, honest, tolerance, discipline, hard work, creative, independent, democratic, curiosity, nationalism, loving the motherland, appreciating achievements, friendly/communicative, loving peace, loving reading, caring for the environment, cocial and responsibility (Kementerian Pendidikan Nasional, 2010). Those characters are taught in various school programs integrated in curriculum and school culture. The portion of the material is reinforced through examples, extracurricular activities, and lifelong learning. Characterization internalization involves instructional impact involving direct knowledge through the content with character values and accompanying impact involving the role and role models of others (Joyce et al., 2003). Besides students knowing essential benefits, the goal is also to make students behave well, have excellent and holistic personality, and develop moral values.

Studies by Sanderse, (2013) stated that teachers less internalize the exemplary teaching methods or role models, even based on adolescents' recognition, only a few of them that make their teachers a role model. However, these methods contribute to moral education. The study of Park, (2019) found a new teaching integrity method in elementary school using four ethical subject components: sensibility, judgment, motivation, and practical skills. Stated that higher education institutions identified a character education and integrity strategy, namely: (1) Making the character as a focus in educating; (2) Developing a healthy institutional culture; (3) Making teacher education programs as an investment (Koskey, 2014). According to Lickona, (2013), a person's character will appear when passing through the value internalization stage, namely: (a) Good knowledge (moral knowing); (b) Honest feelings (moral feeling); (c). Virtuous deeds (ethical action).

In teaching, teacher comprehensively transforms values and characters with many approaches. The teachers can enggage as role models and caregivers, create and practice discipline, democratic classrooms and moral communities, curriculum as a basis for learning values, done cooperatively, develop diligence and conscience, and reflect morals (Lickona, 1993). Studies of Mislia et al., (2016) explained activities outside the classroom, such as scouting, that can build the character; the strategy can be through interventions, modeling, habituation, facilitation, reinforcement, and involving others. This strategy usually includes teachers, parents, and other parties, providing deep concern and creating a positive moral culture at school. The effectiveness education for moral integrity appears when there is good moral knowledge and through integrated learning.

\section{Islamic Boarding School System in Indonesian Context}

The term of "madrasah" is known to be Islamic school as the idea of modernizing Islamic education in Indonesia (Wasik, 2005). The learning program can transform the 
balance of general science and Islamic religious knowledge with the principle of continuation of the boarding school system (Sunhaji, 2017). Islamic school also means that the future orientation of students will be secure in monotheism, personality, and knowledge (Kuswono, 2013). National education policy forms a combination of learning patterns that are structured, dynamic, and balanced, then displaying excellent madrasa (Islamic school) profiles.

On the other hand, the madrasah is equivalent to public schools. Madrasah (Islamic school) and pesantren (Islamic boarding school) have similarities in transforming religious knowledge through learning and acculturation, while pesantren is strict in terms of systems and learning patterns. Both maintain the characteristics of religious education and cultural character (Umar, 2015). Besides that, their function is to transform knowledge, regenerate cadre, and maintain the Islamic culture (Azra, 1998). In other conditions, the policy towards pesantren still receives less attention (Badruddin and Siregar, 2017). In Indonesia, there are three types of the madrasah, namely: (1) Madrasah Diniyah that teaches religious knowledge (Al-Uloom Al-Diniyyah) and elementary and secondary school levels; (2) Madrasah in the SKB 3 Ministerial policy, the transformation from Diniyah to Ibtidaiyah, Tsanawiyah, and Aliyah, and; (3) Islamic boarding schools (Nasir, 2006). This type of madrasah still exists even during urban challenges (Buang, 2008). Operationally, learning in the Islamic boarding schools refers to the concept of Islamic education, organizing holistic education, and integrating curriculum (integrated curriculum). This system integration then displays character, spirituality, skills, and intellectual learning (Sutarman et al., 2017). The strength of the Islamic Boarding School curriculum lies in the capacity of subject matters and character values' internalization. Islamic boarding schools also involve schools, leaders, teachers, subjects, and extracurricular activities integrated with character development through internalization (Amrullah, 2012).

\section{METHOD}

\section{Research design}

This study uses a phenomenological data exploration design to gain a certain person's experiences, and understand the meaning of participants or groups related to social problems (Creswell, 2007). It was conducted at Madrasah Muallimin Muhammadiyah Yogyakarta and determined through phenomena and pedagogical approaches. Furthermore, it reveals the learning symptoms that foster students' integrity and leadership talents, which indicate the phenomena and are naturalistic according to the field conditions (Setyosari, 2016). Therefore, the authors use the following procedures: (1) Tracing printed and electronic literature sources about challenges facing moral integrity education; (2) Determining the impact of the problem, the research object, and performing data collection; (3) Determining the moral integrity value relevant to the National Character, and Culture Education program; (4) Describing and interpreting the participants' experiences in developing and internalizing the moral integrity value; (5) data confirmation, validation, and triangulation; (6) Analyzing, providing the meaning, and recording the findings. 


\section{Participants}

A purposive sampling technique was used to determine the participants or people who understand, have a direct experience of the events and act as national figures, alumni, educators, and organizational leaders. Additionally, the authors appointed Mr. Sarijan (Madrasah Public Relations Officer) as the key informant. However, the research is confined to concept finding, internalization of moral integrity, and superior cadres' leadership. It is also part of the Ph.D.'s dissertation task performed from September 2019 to July 2020 on the onset of the Covid-19 pandemic and was determined by the ease of authors accessibility. Therefore, according to Creswell, (2007) only 5 to 25 were being used in this study considering the data saturation, and their criteria are shown in the table. 1.

Table 1

The data saturation, and their criteria

\begin{tabular}{|c|c|c|}
\hline Participant Criteria & Frequency & Participant Code \\
\hline 1. Alumni / national figures & 3 & ASM-01*, HBI.015, MM-003.Ex, \\
\hline Retired director of madrasah & 3 & MIA-02*, ZU-05*, NF-019, \\
\hline Madrasah leaders & 3 & AA-04*, MLA-07*, DD-020 \\
\hline Active teachers in madrasah & 5 & $\begin{array}{l}\text { SJ-00, MU-08, PUR-010, AN-012, } \\
\text { ZLK-025 }\end{array}$ \\
\hline $\begin{array}{l}\text { 5. Active musrif (student supervisor) in the } \\
\text { boarding }\end{array}$ & 4 & AB-09, ZL-011, RM-013, AGP-014 \\
\hline Alumni / retired teacher & 3 & IH-018, AY-001.Ex, MR-002.Ex \\
\hline Advanced study alumni & 2 & ETS-03*, ZN-06* \\
\hline $\begin{array}{l}\text { 8. Officials of the PP Muhammadiyah Cadre } \\
\text { Education Council and the Daily } \\
\text { Executive Board (BPH). }\end{array}$ & 2 & HA-016, RF-017 \\
\hline Total & 25 & $\begin{array}{l}\text { *An example of a participant interview } \\
\text { is shown in the discussion section. }\end{array}$ \\
\hline
\end{tabular}

\section{Data Collection Procedure and Validity}

The research follows the following steps before data collection: (1) Identifying participants, and location using the suggestions, and information from the Madrasah Public Relations section; (2) Object accessibility; (3) Classifying the informant; (4) Developing data collection instruments; (5) Data collection through administering and focusing on the research problem. Since there was a natural setting, the data collection procedure was directly conducted in the field (Creswell, 2012).

The data collection techniques include: (a) Participatory observation technique (Sugiyono, 2017), as proposed by the qualitative researcher because the direct involvement of the authors is vital in situation learning and recording narrative notes; (b) In-depth and semi-structured interviews, where the participants are asked about cognitive understanding, and interpreting their experiences. The model is picked due to its close focus on the problems and the ability to explore the subjective experiences. Furthermore, both parties agreed on the time and place, and the interview was done between 30 minutes and 1 hour, followed by data transcription. Observation and interviews were done using guidelines and question notes from the topics and confirmation instruments from expert consultation; (c) Investing in relevant documents 
such as superior cadre education guidelines and files of the past events to strengthen previous techniques, and; (d) Participating in a Focus Group Discussion (FGD) (Bandur, 2016), and evaluation of the Madrasah Daily Management Board to understand the cadre education implementation. This procedure also involved validation through triangulation of the sources, data and results, member checking, discussions and confirmations data interpretations, extending study time and increasing persistence, analyzing new cases, and recognition (Creswell, 2012; Miles et al., 2014).

\section{Data analysis}

Data analysis steps used are adapted from interactive flow (Miles et al., 2014) in which the collected data was organized, described, analyzed, and interpreted for credible, accurate, and justifiable results. Thereafter, the analysis followed this sequence: (1) Condensation, authors select, simplify, classify, and categorize data from the observations, transcripts of informant interviews, picture documents, and empirical facts in madrasah boarding school according to their objectives; (2) Findings presentation, after categorizing it, the results are presented as research information and compared with other sources; (3) Conclusion, the authors give the final results and present the significance of moral integrity education while focusing on the full set of field notes.

\section{FINDINGS}

The results are further presented sequentially based on the themes and objectives of the study, including the cadre education concepts, the formation direction, and internalization of moral integrity and leadership as follows;

First, formulating the development of six-years superior cadre's concept in madrasah boarding schools, which is similar to the promoting human resources concept in the Muhammadiyah education reform movement at the student level. Therefore, "superior cadre" refers to "student" or "santri" (Islamic student), who is fostered with Islamic, and Muhammadiyah values and displays the character of outstanding future leaders, cadres, and educators. Based on all data collection techniques, the vision formulation to the learning program identified the cadre education concept at the madrasah boarding school as oriented towards continuous education, a balance to the needs, and basic spiritual. Furthermore, it identifies cognitive, affective, and leadership skills that link the process of internalizing students' values and morals from early adolescence to late adolescence. Therefore, all subjects in this category explain the development of morals and character, skills, and cadre's life principles.

The data reduction results show that the components are integrated into the superior cadre's formation. Moreover, the characteristics and learning culture at madrasah boarding school emphasizes the education of cadres (students) at the Madrasah Tsanawiyah level (junior high school level), and Madrasah Aliyah (senior high school level) with the basic science, and Islamic and lifelong education knowledge. The learning culture is also supported by teachers, musrif (boarding supervisor), mujanib (student companion), parents, alumni, and the community. Furthermore, vision, mission, goals, and integrative curriculum are essential in orientating and implementing cadre programs and learning culture. Therefore, this process affirms the motto and displays the 
learning output, such as "superior learners (cadres), future cadres candradimuka, and Muhammadiyah arrows" who are ready to serve the wider community.

The concept of superior cadre education is shown in the Figure. 1 as follows:

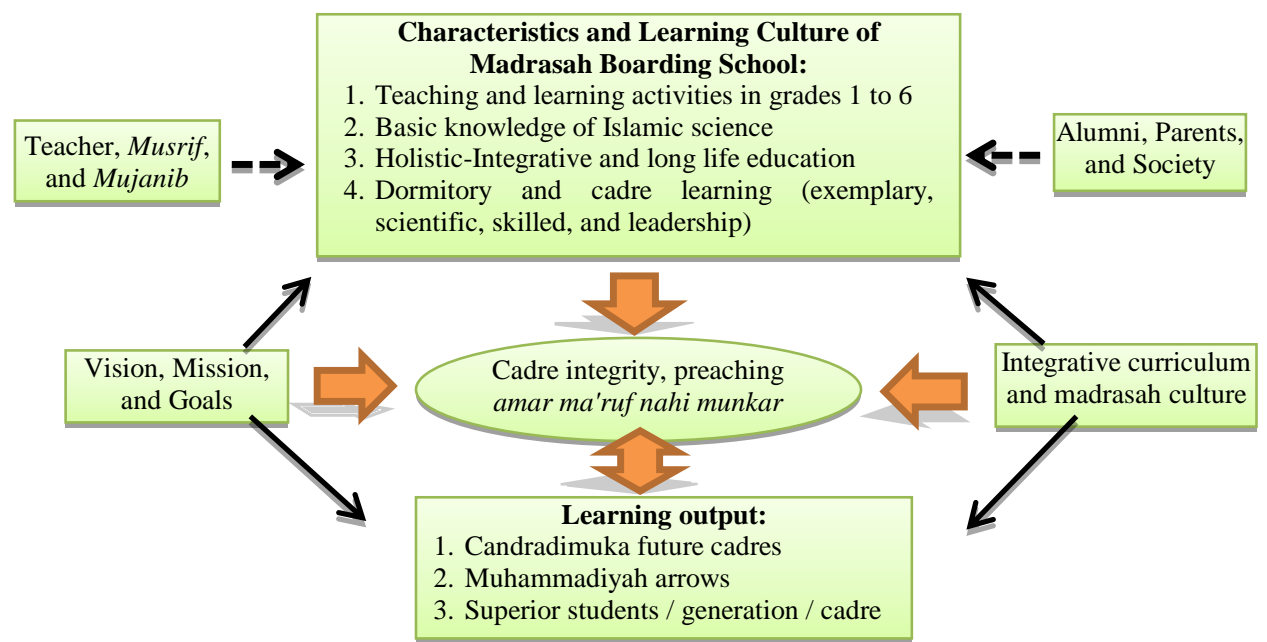

Figure 1

The concept of superior cadre education

The cadre program is formulated in the cadre handbook, including formal learning. Moreover, it is done through systematic training consisting of two groups: (1) New Student Orientation Forum; (2) Muhammadiyah Student Association Integrated Cadre Training, with extracurricular activities, such as Hizbul Wathan (scouting) Basic Leadership Training, Muallimin Da'wah Corps, Youth Scientific Group, Youth Red Cross, Sports, and Tapak Suci (martial arts college). This training involves all students from grade 1 to 6 at Madrasah Tsanawiyah for six years. Furthermore, the implementation consists of two student groups: (a) Grades 1 to 3, which provide knowledge and instill the moral values and Islamic behavior awareness, knowledge and aspirations awareness, community ownership, leadership spirit, independent life, maturity, and broad insight; (b) Grades 4 to 6, developed critical thinking of adolescent students, leadership and pioneering spirit, function as a successor regeneration process to creates superior and militant cadres, and facilitates their skills training activities (Training of Trainer). Kemuhammadiyahan is also done as a General Stadium (Tim Materi, 2017) to strengthen ideology and leadership. For students to pursue the final stage of the 6-year cadre education, there were several exercises to determine their potential, including writing a paper, sermons in the community, Darul Arqam Purna (final stage cadre training), interviewing cadres (finishing touch), providing commitment, and seriousness in community participation.

From the above formulation, the learning curriculum helps in the implementation of a six-year cadre education, which considers the following: (1) The religious science 
learning structure is integrated with general science, which balances between theory and practice; (2) Strengthening and practicing the basics of Islamic religious knowledge, and cadre through mentoring; (3) Lifelong learning uses exemplary approaches, scientific learning, strengthening skills, and leadership, to superior personalities that guarantee knowledgeable cadres (Tim Penyusun, 2012).

Second, superior cadres' education in madrasah boarding schools promotes moral integrity and leadership formation. Based on the results of reduced observation data, indepth interviews, supported by documented studies, contain value domains, sub-values, and indicators that confirm the direction in the moral integrity and leadership formation. However, madrasah develops the domain of learning values in the cadre's development principles, as leadership cadres, humanity, nationality, association, and educators. Furthermore, this domain is a focus and blueprint of madrasah boarding schools towards developing learning and cadre program policies. For instance, each value domain has sub-values internalized directly by all leaders, teachers, employees, musrif, and mujanib. Therefore, sub-values are goals grown in each cadre through various aspects, such as internalization of habituation, good behavior, during and after learning, and in madrasah culture. Table 2 shows the moral action expected from the performance indicators after realizing self-integrity.

Table. 2

The values development in superior cadres' education leads to moral integrity at Madrasah Muallimin Muhammadiyah Yogyakarta

\begin{tabular}{lll}
\hline Values Domain & Sub Value & Outcome indicators \\
\hline Leadership & $\begin{array}{l}\text { Independent, disciplined, honest, authentic } \\
\text { behavior, responsibility, critical, optimistic, } \\
\text { consistent, high achievers, communicative, and } \\
\text { confident. }\end{array}$ & $\begin{array}{l}\text { Leader and integrity } \\
\end{array}$ \\
\hline Humanity & $\begin{array}{l}\text { Sensitive, caring, cooperative, critical, tolerant, } \\
\text { and communicative. }\end{array}$ & $\begin{array}{l}\text { Social care people as part of the } \\
\text { community members }\end{array}$ \\
\hline Nationality & Nationality, peace-loving, and critical. & Nationalism and national integrity \\
\hline Organization & $\begin{array}{l}\text { Religious, authentic, sense of belonging, } \\
\text { responsibility, critical, and confident. }\end{array}$ & $\begin{array}{l}\text { Have integrity as a cadre of the } \\
\text { Muhammadiyah organization }\end{array}$ \\
\hline $\begin{array}{l}\text { Educator / } \\
\text { Teacher }\end{array}$ & $\begin{array}{l}\text { Creative, optimistic, patient, compassionate, } \\
\text { role model, wise, passionate, confident, } \\
\text { consistent, critical, and achievers. }\end{array}$ & $\begin{array}{l}\text { Competent, able to teach and } \\
\text { imitate, with the integrity of } \\
\text { prospective educators. }\end{array}$ \\
\hline
\end{tabular}

Third, the subjective experience of learners in internalizing moral integrity occurs in different conditions for the same cadres and students. Furthermore, the process of internalizing the values in this category is similar to the procedure followed by all parties in teaching the moral integrity value. This is because the teacher internalizes the study hours at the madrasah, as Musrif develops it in the boarding, and vice versa. Furthermore, all students' activities focus on strengthening various moral values, including exemplary and deeds, habituation, obedience, showing leadership authority, polite communication, inspiring, and family role models for teachers and madrasah elements to foster integrity. 
According to the internalization process, "Ust. Pwn" homeroom teacher at Madrasah Tsanawiyah conducts classroom learning from 06.50 am to $01.55 \mathrm{pm}$, while each lesson begins with 10 minutes of Al-Qur'an reading. Additionally, some learning materials involves active learning and use the STIFIN method, which arouses students' curiosity, self-potential, talents, and intelligence. Furthermore, the madrasah teachers and leaders habituate through the 5-S "Smile, Greetings, Salutations, Manners, Polite", which portrays students behaving the same way towards others. A musrif in Dormitory 1, "Ust. $\mathrm{Ab}$ " internalizes discipline and consistently performs five times daily prayers at the mosque, which assists students to develop skills, cleanliness, and cooperation to familiarize themselves with morning and evening tadarus (reciting Al-Quran) with short lectures. Moreover, there is a moral character Internalization in integrated and included madrassas and dormitories for 24 hours starting from 04.00 am to $10.00 \mathrm{pm}$.

To support moral internalization, madrasah learning program involves the following: (1) Interactive outdoor, science camp, outbound students, leadership, and "Hizbul Wathan" tough through direct practice in community life and open nature; (2) Students practicing leadership organizations, such as handling many friends, decision making, and evaluating activities; (3) Community involvement as a control based on the madrasah geographic location, and the distribution of boarding in the community hence, they interact directly. This impacts their attitudes and morals, including consistency of obligatory prayers in mosques, joining madrasah and returning to the boarding, responding (shaking hands) with people, strengthening relationships, and praying together for disaster victims, and their sick families; (4) Strengthening cadres' ideology and integrity through guidance, general lectures on Islamic, Kemuhammadiyahan, social, organizational, and competency encouragement ahead of the national examination. This phase involves national figures, government officials, full-service teachers, and alumni who are in the Madrasah Mu'allimin Mu'allimat Muhammadiyah Abiturient Family Association.

From the results, the internalization of moral integrity values happens directly and indirectly in the classroom learning, independent and discipline learning in boarding, interests, and talents development in organization and leadership. Furthermore, a culture of encouragement and inspiration is one of the core values of leadership and personality, consistency of rules, impression, and democratic choices. This study divides the developing superior cadre's concept realization into two significant factors; the madrasah learning program with the internalization of moral values integrated into formal learning in class. Additionally, it is conducted through structured and systematic training and orientation, whose implementation considers input, process, and output including quality and excellence objectives as stipulated in Madrasah Standard Operating Procedures and Strategic Plans.

\section{DISCUSSION}

Formulating the superior cadre education concept in fostering moral integrity and leadership is based on the vision, mission, and objectives of the madrasah, curriculum, and learning programs. Therefore, moral learning in madrasah boarding schools is all parties' responsibility since every educator is important, and believes it is a noble task to 
nurture cadres with high moral standards and scientific competence, which makes them realize their goals. Furthermore, cadre training has is recognized as a madrasa's characteristic, differentiating it from others. Alumni in 1989, former 2005-20113 director, and active teachers emphasized:

"There is an initial indication and purposive idea by K.H. Ahmad Dahlan which is only not directly systematic or documented but also contains learning values that are certainly focused on moral and character direction. The founders also set a goal, vision, and mission document in 1986, that later became the benchmark for cadre training" (Participant Interview, Code MIA-02).

The highest director in Madrasah also released a similar statement saying:

"Muallimin, which is specifically a cadre school at the student level, was entrusted to Mukhtamar and fostered directly by the Muhammadiyah Central Leadership. Its vision is to prepare superior cadres, such as Muhammadiyah leaders for future tasks. Excellence in cadre leaders, ulema, and educators, is philosophically understood as qualifications for scientific competence, personality and character, skills, social and movement aspects, with a comprehensive organizational spirit" (Participant Interview, Code AA-04).

The madrasah vision was established to respond to changes in values and socio-culture, the need for ideal education, religious knowledge, and the bearer of the amar ma'ruf nahi mungkar, prospective Muhammadiyah leaders. Furthermore, it focuses on the future of the Indonesian nation, the followers, and humanity based on ideological and cultural goals to accommodate potential successors. The successors are responsible for leadership and agents of change, which are insightful, forward-thinking, intelligent, and have integrity (Tim Penyusun, 2008). The existence of madrasah also proves the historical dynamics of the education development, for instance through educating the prospective ulema (Muttaqim, 1995), and the initial stages of producing superior cadres (Azhar et al., 2016). This is emphasized by national figures and madrasah education developers, alumni of 1950 and 1967, and the former director of 1999-2005 who said:

"The realization of a superior generation as the spearhead of the future gives good insights for Muhammadiyah. After becoming alumni, the students have the idea of serving the state, nationality, and humanity in their respective fields. We want the students motivated and free, have a broad Islamic, Indonesian, and human insight. This makes the expected character to stand out as a culture of confidence and potential leader" (Participant Interview, Code ASM-01).

"Since we were in Muallimin, we must be broad examples and consistent with any situation for us to lead the followers. I have been teaching since 1967 on the formation of leadership cadres, and I really see and feel it" (Participant Interview, Code ZU-05).

The concepts and orientations above are revealed to be the implementation of learning in every culture and life in madrasah and Islamic boarding schools. As a result, there is a mutually beneficial learning interaction between teachers and students, which involves giving examples by showing exemplary interactions that are most common in value, and 
character education. Civilization in the wider community is established by the involvement of alumni who serve as educators, preachers, and organizational leaders at the local and national levels, and other professional fields. Therefore, this a reinforcement of K.H. Ahmad Dahlan's idea regarding the objectives of Muhammadiyah education, including moral education, attitude, and human character from the Al-Qur'an and Hadith, as well as individual and community education (Arifin, 1987). 2002 alumni, who served as deputy director of curriculum and teaching, interprets the concept of superior cadre education, moral integrity, and leadership as follows:

"Superior cadres have a strong basic character, and they can be anything, although being a leader needs to have character. Periodically, the original character of the Muallimin cadres is difficult to be influenced, because they have the abilities. The Muallimin curriculum is known as the crossing curriculum, which is a combination of the curriculum from national education, the Ministry of Religion, and the Islamic boarding school. Therefore, this system presents cadre education as its hallmark, with integrated cadre development consisting of: (1) Grade promotion; (2) The value of report cards is not a major determinant in grade promotion; (3) If the report card portrays excellent performance but does not carry out cadre programs such as Muballigh Hijrah, there is no grade promotion. The derivatives of this program are in the academic and teaching fields with several subjects including leadership, kemuhammadiyahan, tarjih, and selfmanagement. Furthermore, the third Deputy Director contains Baitul Arqam 1 to 6, Tapak Suci (martial arts college) coaching, and Hizbul Wathan (scouting) for cadre training” (Participant Interview, Code MLA-07).

According to the opinion of the 2001 alumni on leadership, teachers interpreted their experiences during the study by stating: "I think it is a unit that is not separate but integrated with pre-student education to the final grade VI, namely Darul Arqam" (Participant Interview, Code.03). Confirming the findings by Widodo, (2018); Widodo et al., (2019), Muhammadiyah education has developed holistically and harmoniously through culture by emphasizing emotional, social, spiritual, creative, and physical potential. Therefore, the formulation of a holistic and integrative based learning curriculum is vital in fostering moral integrity. Learning, which combines Islamic knowledge and general science, support for boarding culture, cooperation between elements of teachers, musrif, mujanib, alumni, parents and the community allows the growth of a generation with superior character, competent and insightful, trustee, leader integrated and propagation of social changes.

From the madrasah boarding school, the indicators of superior cadre education lead to the formation of moral integrity and leadership. The participant's statement and meaning confirm that:

"Being a leader needs something prominent because Muallimin students behave authentically, while these values have to be upheld by the present and future national generations. Consequently, madrasah have the potential to maintain the distinctiveness. Building integrity can be done through the aspects of cadre development, which requires absolute morals and intellectuals. Therefore, the leaders will have a fragile foundation without these aspects" (Participant Interview, Code ASM-01). 
"First, the aspect of self-confidence is not changed from ancient times until now hence, the students of Muallimin still have extraordinary self-confidence. The important thing is the bravery to act fast regardless of sufficient capacity. Second, on the organizational skills, the students should be committed and practice a lot in the leadership aspect from grades 1, 2, and 3" (Participant Interview, Code AA-04).

"We teach leadership lessons in a small area, such as classroom, family, Muhammadiyah members, and the wider community. Therefore, they have to own integrating personality, which does not easily take sides. We also train the students to be honest both in words and behavior, which is the core of integrity. Furthermore, there has to be a coherence between the words and behaviors, and they also have to be ready and committed to lead" (Participant Interview, Code ETS-03).

"As a consequence, the students should become the superior frontline and have a high sense of belonging to Muhammadiyah" (Participant Interview, Code ZN-06).

Respondents have interpreted integrity as a moral character and belief, which is integrated into their identity and is held firmly as a cadre's life principle. Therefore, the formation of moral integrity is developed by cultivating the values of independence, honesty, discipline, leadership, confidence, commitment, and consistency in choice. Moreover, the superior and perfect cadres should respect and accept differences, forgive others, being open-minded, behave authentically, perform as role models, and have a sense of belonging. This is under the findings of qualitative studies, which shows that madrasah contribute positively and significantly to academic development, and national character (Ma'zumi, 2012; Wahyuni, 2017; Madjid, 2018). However, the study challenges the allegations and assumptions that madrasah are still underdeveloped and less competitive in terms of curriculum, management, student academic achievement, low affective education, and significantly different from public schools (Mukhlis, 2017). Furthermore, it dispels the accusations that promote madrasah and linking them to militancy, extremism, and teaching politics (Arif et al., 2017). Ideally, learning in madrasah has responded to negative allegations that highlight the academic integrity of students and less moral values teaching (Stephens dan Wangaard, 2013; Piascik dan Brazeau, 2010).

Culture and learning interactions in the madrasah ecosystem significantly support the growth of moral attitudes, integrity, and similarity to the vision. According to Rahman et al., (2020) character education based on school culture effectively increases student character. As a result, it realizes the cooperation between the teacher, musrif, and students, while mutually supporting the internalization of integrity morals. According to Hayati and Mayasari, (2019), educators and students with low understanding and commitment to integrity experience difficulties in learning practices. Therefore, the better the learning pattern, the higher the integrity value of students and vice versa hence, influencing academic success.

The development of moral integrity and leadership is also influenced by a series of classroom and outdoor learning programs, organizations, systematic, humanist, active, and dialogic strengthening of ideology. This seconds the study by Cahyo et al., (2019), 
which shows that character education in school culture harmonizes various programs and fosters an integrity character. Moreover, Sulaiman, (2010) stated that mujanib played a role in student leadership at madrasah, hence, learning leads and cultivates leadership talent.

The process of internalizing moral integrity and leadership is done in different conditions. In interpreting the experience, the participants state as follow:

"I obtained thousands of examples, and a small piece of advice from teachers and figures, and learned that when teaching discipline and time management, they only read a little theory, but directly practice discipline and honest behavior in their daily life. They also have al-wala' wal bara' and that personality sinks into my heart. We conduct incidental programs that every saturday night, the students follow Muhadaroh training and speeches. Moreover, on friday mornings they join leadership training sessions such as organizing their friends, community service, and cleaning consecutively. In the Islamic student organization, program planning, implementation, and evaluation is managed independently" (Participant Interview, Code MIA-02).

“The teachers' methods of teaching are different, although some of them are supportive, inspiring, and intriguing. I teach leadership through exemplary by introducing leadership models. For instance, i take leadership models from the alumni and the Muhammadiyah founder of K.H. Ahmad Dahlan, which illustrates his great service hence, the community felt the benefits. I also take the leadership example from Mr. AR Fahruddin, the chairmen of Muhammadiyah leadership, the directors of Muallimin, the former chancellor of the Muhammadiyah University of Yogyakarta, the parliament and state institutions figures, and Buya Syafii Maarif as a national figure. Moreover, we give concrete examples as they observe the characteristics of their respective leadership. Sometimes, i challenge and invite the students to think and have a dialogue" (Participant Interview, Code ETS-03).

"Musrif accustomed us to self-discipline in the boarding, starting from the time we wake up until sleeping hours. We also give examples of friends as leaders and as cadre candidates. Additionally, in every activity, teachers remind that each of you is a leader, and should be responsible for your leadership" (Participant Interview, Code ZN-06).

"Ust. Zamzuri is impressive in communication, and i observe the way he speaks philosophically. Furthermore, he is firm and always gives a logical understanding, for instance, the way he calls the students "younger siblings" gives a good impression and exemplifies the moral values of my family, such as being polite and wearing a headscarf. This attitude shows their impression" (Participant Interview, Code MLA-07).

Internalization is built through the provision of exemplary, independent practice, obedience, and leadership examples. According to Brata et al., (2017), Atmajawati and Utomo, (2018), internalization played by many parties affects the students' quality, excellence, loyalty, and personality. Besides the learning treatments formulated by teachers, and musrif, moral internalization is also supported by learning strategies involving certain roles stated called the nurturant effect (Joyce et al., 2003). Furthermore, the learning climate indicates a balanced value internalizing process, 
hence, this study affirms that in a century, madrasah play a strategic role in presenting superior generations.

Apart from focusing on the rule model scheme, the internalization strategy also creates a conducive learning environment, strengthening cadres' ideology, training, and leadership programs, and enhances individual character experiences. According to Stephens and Wangaard, (2013), achieving integrity requires the development of an approach that focuses on moral awareness, judgment, commitment, and action. Furthermore, Tull et al., (2009) suggest that integrity internalization should be done following the experiential learning methods, cognitive approaches, observations, and briefings. Therefore, moral experience impacts worship, leadership morals, clergy, and independence aspects.

\section{CONCLUSIONS AND RECOMMENDATIONS}

The conclusions of this research are: (1) The concept associated with fostering superior cadres for six-years is a lifelong education process that internalizes character and morals, develops spiritual and physical skills in adolescent students through cadre programs, madrasa culture, and dormitory life, and by involving the collective roles of teachers, alumni, parents, and the community. The creation of superior cadres is an essential factor for madrasas used to maintain moral education's blueprint due to changes in values. This concept is recognized as a characteristic of madrasah education, which is influenced by the spirit of Muhammadiyah education "living and giving life" founding father's leadership, modern integrated-holistic learning system, the involvement of madrasah elements in developing a leadership culture and ideology of cadres; (2) The domain values in the education of superior cadres prove that the concept of learning leads to the formation of prospective leaders with Muhammadiyah ideology, strong nationalism, humanism, and high moral integrity. This is achieved by maintaining a boarding school madrasah education base that educates adolescent students' integrity to face dialectics as adults. Meanwhile, graduates with good leadership spirit and integrity possess good culture and learning interactions in line with current character education. Therefore, developing cadres is suitable for fostering leadership skills that provide positive leadership talents in future generations. The output is an agent of change that is felt, needed, and sought after in the community; (3) Learners recognize that internalizing the moral value of integrity is formed by formulating the learning environment in madrasah and dormitories by behaving authentically, appearing as role models, and having a sense of belonging. It is also associated with inspiration, honesty, responsibility, discipline, independence, commitment, and consistency, thereby forming an integrated character with identity and belief held firmly as a principle of life.

This research recommends the importance of stakeholder support and Indonesian education providers in successfully providing responsible adolescent students through better boarding school madrasah learning patterns. Furthermore, this research can be used as a reference for moral education in Islamic education and public schools. Further research on moral integrity and leadership education need to be expanded and deepened by considering different paradigms, methods, or measurements in the future. In addition, this is a significant value that can be used to identify other moral values. 


\section{ACKNOWLEDGMENTS}

The authors expressed gratitude to the Ministry of Religion of Indonesia (MORA) and all the corresponding authors at the University of Malang for their support and guidelines towards the research.

\section{REFERENCES}

Amrullah, A. M. K. (2012). Implementasi Pendidikan Karakter di Madrasah. Jurnal Pendidikan Dan Pembelajaran Dasar, 4(2), 187-199.

Anam, S., Degeng, I. N. S., Murtadho, N., \& Kuswandi, D. (2019). The moral education and internalization of humanitarian values in pesantren. Journal for the Education of Gifted Young Scientists, 7(4), 815-834. https://doi.org/10.17478/jegys.629726

Arif, M. I. A. M., Rahman, N. H. A., \& Hanapi, H. (2017). Madrasah Education System And Terrorism: Reality And Misconception. International Journal of Educational Best Practices, 1(1), 83. https://doi.org/10.31258/ijebp.v1n1.p83-92

Arifin, M. T. (1987). Gagasan Pembaharuan Muhammadiyah dalam Pendidikan. Pustaka Jaya.

Atmajawati, Y., \& Utomo, H. W. (2018). Learning Method, School Environment, Leadership and Its Effect on Quality Education and the Excellence Student Character at Muhammadiyah High School. Journal of Education and Practice, 9(26), 118-123.

Azhar, A., Wuradji, W., \& Siswoyo, D. (2016). Pendidikan Kader Dan Pesantren Muallimin Muhammadiyah Yogyakarta. Jurnal Pembangunan Pendidikan: Fondasi Dan Aplikasi, 3(2), 113-125. https://doi.org/10.21831/jppfa.v3i2.9816

Azra, A. (1998). Esei-Esei Intelektual Muslim \& Pendidikan Islam. Logos Wacana Ilmu.

Badruddin, P. Y., \& Siregar, N. C. (2017). Pesantren dalam Kebijakan Pendidikan Indonesia. Jurnal Lektur Keagamaan, 15(1), 233-272. https://doi.org/https://doi.org/10.31291/jlk.v15i1.522

Badruzzaman, B. (2019). Integritas Siswa Sekolah Menengah Atas di Kawasan Timur Indonesia, (Pengaruh Tingkat Kondusifitas Lingkungan Terhadap Integritas Siswa). AlQalam, 25(1), 77. https://doi.org/10.31969/alq.v25i1.729

Baharom, M., Halimatus Saadiah, M. S., \& Sharifah Hayaati. Syed Ismail. (2014). The role of integrity as a mediator between work satisfaction and work performance in the perspective of Islam: An empirical approach using Sem/Amos Model. International Journal of Research in Applied, Natural and Social Sciences, 2(1), 71-84. http://umexpert.um.edu.my/file/publication/00002823_99942.pdf

Bandur, A. (2016). Penelitian Kualitatif Metodologi, Desain, dan Teknik Analisis Data dengan NVIVO 11 Plus (M. W. Media (ed.) 
Becker, T. E. (1998). Integrity in Organizations: Beyond Honesty and Conscientiousness. The Academy of Management Review, 23(1), 154-161. https://doi.org/10.2307/259104

Betawi, A. (2018). Calling for character education: promoting moral integrity in early childhood education in Jordan. Early Child Development and Care, 1-12. https://doi.org/10.1080/03004430.2018.1489383

Brata, D. P. N., Imron, A., K.H, A. S., \& Arifin, I. (2017). Headmaster Leadership Behavior in Strengtening Character Values In Vocational High School. IOSR Journal of Humanities and Social Science, 22(06), 07-12. https://doi.org/10.9790/08372206060712

Buang, S. (2008). Madrasah and Muslim Education: Its Interface with Urbanization. International Handbook of Urban Education, 321-341. https://doi.org/10.1007/978-14020-5199-9_17

Cahyo, U. B., Suyahmo, \& Karyono. (2019). Implementation of Character Education for Creating Integrity Schools A Case Study At Public Junior High School 2 Pekalongan in 2015. Journal of Educational Social Studeis, 8(59), 111-119. https://journal.unnes.ac.id/sju/index.php/jess/article/view/34578/14343

Creswell, W. J. (2007). Qualitative Inquiry and Research Design Choosing among Five Approaches. Thousand Oaks CA: Sage Publications.

Creswell, W. J. (2012). Educational Research, Planning, Conductin and Evaluating Quantitative and Qualitative (Four Edition). Person.

Dunn, P. C. (2009). Integrity matters. European Pharmaceutical Contractor, AUTUMN, 114-117.

Erhard, W. H., Jensen, M. C., \& Zaffron, S. (2017). Integrity: A positive model that incorporates the normative phenomena of morality, ethics, and legality (abbreviated version). In Integrity in Business and Management: Cases and Theory (Issue January 2010). https://doi.org/10.4324/9781315750477

Fakhruddiana, F., \& Sulisworo, D. (2017). Balancing the Developmental Aspect on Value Based Character Building through Boarding School System in Indonesia. 4th International Conference the Community Development in ASEAN, 267-275.

Gea, A. A. (2014). Integritas Personal dan Kepemimpinan Etis. Humaniora, 5(2), 950. https://doi.org/10.21512/humaniora.v5i2.3197

Hardaker, G., \& Sabki, A. A. (2015). Islamic pedagogy and embodiment: an anthropological study of a British Madrasah. International Journal of Qualitative Studies in Education, 28(8), 873-886. https://doi.org/10.1080/09518398.2014.917738

Hayati, \& Mayasari, E. (2019). The Implementation of Integrity Learning Through Entrepreneurship Activities and Anti-Corruption Behavior. Jurnal Ilmiah Peuradeun, $7(2), 285-294$. 
Hornby. (2010). Oxford Advanced Learner's Dictionary, International Student's Edition (Eight). Oxford University Press.

Horowitz, M. (2001). Defining Character Integrity. Journal of the American $\begin{array}{lll}\text { Psychoanalytic Association, 50(2), 551-573. } & \end{array}$ https://doi.org/10.1177/00030651020500021601

Huberts, L. W. J. C. (2018). Integrity: What it is and Why it is Important. Public Integrity, 20(1), 18-32. https://doi.org/10.1080/10999922.2018.1477404

Joyce, B., Marsha, W., \& Calhoun, E. (2003). Models of Teaching (Fifth Edition) (This Fifth). Indian, Reprint.

Kamdi, W. (2009). Active Learning di antara Idealisasi dan Realitas Praktik Pendidikan.

Karthikeyan, P. C. (2017). A Meta Analytical Study on Leadership Integrity: A leadership Ethics Perspective. International Journal of Management, IT and Engineering, 7(4), 240-263.

Kementerian Pendidikan Nasional. (2010). Bahan Ajar Pelatihan Penguatan Metodologi Pembelajaran Berdasarkan Nilai-Nilai Budaya Untuk Membentuk Daya Saing dan Karakter Bangsa. Kementerian Pendidikan Nasional Badan Penelitian dan Pengembangan Pusat Kurikulum.

Koskey, J. (2014). The Centrality of Character and Integrity Education in Kenya's Institutions of Higher Learning. Asia Pacific Journal of Multidisciplinary Research, 2(1), 47-56. http://oaji.net/articles/2014/1543-1418694306.pdf

Kusuma, D. (2011). Pendidikan Karakter, Kajian Teori dan Praktek di Sekolah. Remaja Rosdakarya.

Kuswandi, D. (2009). Bangunan Keilmuan Pendidikan Taman Siswa. Jurnal Ilmu Pendidikan, 3(2).

Kuswono. (2013). Character Education Muhammadiyah Pattern (Case Study SMA Muhammadiyah 1 and MA Muallimin Yogyakarta). GUIDENA: Jurnal Ilmu Pendidikan, Psikologi, Bimbingan Dan Konseling, 3(1), 42-49. https://doi.org/https://doi.org/10.24127/gdn.v3i1.374

Lickona, T. (1993). The Return of Character Education. Educational Leadership, 51(3), 6-11.

Lickona, T. (2004). Character matters: How to help our children develop good judgment, integrity, and other essential virtues. Simon and Schuster.

Lickona, T. (2013). Education For Character (Mendidik untuk Membentuk Karakter). Bumi Aksara.

Ma'zumi, J. (2012). Contributing of Madrasah to the Development of the Nation Character. International Journal of Scientific \& Technology Research, 1(11), 37-39. 
https://www.ijstr.org/final-print/dec2012/Contributions-Of-Madrasah-To-TheDevelopment-Of-The-Nation-Character.pdf

Madjid, A. (2018). Full Day School Policy for Children's Character Development: Lesson From Indonesian Islamic Education. The Online Journal of New Horison In Education, 8(3), 51-60.

Miles, M. B., A. Michael, H., \& Saldana, J. (2014). Qualitative Data Analysis A Methods Sourcebook (3 Edition). SAGE Publications, Inc.

Mislia, M., Mahmud, A., \& Manda, D. (2016). The Implementation of Character Education through Scout Activities. International Education Studies, 9(6), 130. https://doi.org/10.5539/ies.v9n6p130

Mitchell, L. A. (2015). Integrity and virtue: The forming of good character. Linacre Quarterly, 82(2), 149-169. https://doi.org/10.1179/2050854915Y.0000000001

Mukhlis, A. B. (2017). Rethinking madrasah education in a globalised world. In Routledge. Routledge. https://doi.org/10.4324/9781315184234

Musschenga, A. W. (2001). Education for Moral Integrity. Journal of Philosophy of Education, 35(2), 219-235. https://doi.org/10.1111/1467-9752.00222

Musschenga, A. W. (2002). Integrity - Personal , Moral , and Professional. Springer, Dordrecht.

Muttaqim, A. (1995). Madrasah Mu'allimin Muhammadiyah Yogyakarta (Studi tentang Dinamika Pembaharuan Sistem Pendidikan Kader Ulama. http://digilib.uinsuka.ac.id/15307/

Nasir, M. R. (2006). Mencari Tipologi Pendidikan Ideal. Pustaka Pelajar.

Nillsen, R. (2004). The Concept of Integrity in Teaching and Learning. Symposium on Promoting Academic Intergrity, 2(November 2004), 1-9. https://www.researchgate.net/publication/30385325_The_Concept_of_Integrity_in_Tea ching_and_Learning

Noelliste, M. (2013). Integrity: An Intrapersonal Perspective. Human Resource Development Review, 12(4), 474-499. https://doi.org/10.1177/1534484313492333

Nucci, L. P. (2001). Education in the moral domain. In Cambridge University Press (Vol. 39, Issue 04). Cambridge University Press. https://doi.org/10.5860/choice.39-2324

Pala, A. (2011). The Need for Character Education. International Journal of Social

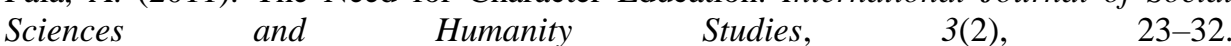
https://www.researchgate.net/publication/267824613_THE_NEED_FOR_CHARACTE R_EDUCATION

Park, Y. G. (2019). Contents for Integrity Education at the Elementary School in South Korea using 4 Components Theory of Morality made by J. Rest. The Journal of the Korea Contents Association, 19(11), 653-663. https://doi.org/https://doi.org/10.5392/JKCA.2019.19.11.653 
Piascik, P., \& Brazeau, G. A. (2010). Promoting a culture of academic integrity. American Journal of Pharmaceutical Education, 74(6), 1-2. https://doi.org/10.5688/aj7406113

Rahman, H., Jamaluddin, \& Umar. (2020). The Development of Character Education Model Based on School Culture. 1st Borobudur International Symposium on Humanities, Economics and Social Sciences (BIS-HESS 2019), 436(5), 596-601. https://doi.org/10.2991/assehr.k.200529.125

Raihani, R. (2012). Islamic Schools and Social Justice in Indonesia: A Student Perspective. Al-Jami'ah: Journal of Islamic Studies, 50(2), 279. https://doi.org/10.14421/ajis.2012.502.279-301

Sanderse, W. (2013). The meaning of role modelling in moral and character education. Journal of Moral Education, 42(1), 28-42. https://doi.org/10.1080/03057240.2012.690727

Schuyler, K. G. (2010). Increasing Leadership Integrity Through Mind Training and Embodied Learning. Consulting Psychology Journal, 62(1), 21-38. https://doi.org/10.1037/a0018081

Setyosari, P. (2016). Metode Penelitian Pendidikan dan Pengembangan (Keempat). Kencana.

Sihombing, S. O. (2018). Youth perceptions toward corruption and integrity: Indonesian context. Kasetsart Journal of Social Sciences, 39(2), 299-304. https://doi.org/10.1016/j.kjss.2018.03.004

Singh, A. (2011). Evaluating the Impacts of Value Education: Some Case Studies. International Journal of Educational Planning \& Administration, 1(1), 1-8. http://www.ripublication.com/ijepa.htm

Stephens, J. M., \& Wangaard, D. B. (2013). Using the Epidemic of Academic Dishonesty as an Opportunity for Character Education: A Three-Year Mixed Methods Study (with Mixed Results). Peabody Journal of Education, 88(2), 159-179. https://doi.org/10.1080/0161956X.2013.775868

Sugiyono. (2017). Metode Penelitian Kualitatif, Untuk Penelitian yang Bersifat Eksploratif, Enterpretif, Interaktif dan Konstruktif. CV. Alfabeta.

Sulaiman, M. (2010). Peranan Mujanib Terhadap Kepemimpinan Siswa Madrasah Mu'allimin Muhammadiyah Yogyakarta Tahun Pelajaran 2008/2009 [Universitas Muhammadiyah Surakarta]. http://eprints.ums.ac.id/9106/

Sunhaji. (2017). Between social humanism and social mobilization: The dual role of Madrasah in the landscape of Indonesian Islamic education. Journal of Indonesian Islam, 11(1), 125-144. https://doi.org/10.15642/JIIS.2017.11.1.125-144

Supa'at, S. (2014). Model Kebijakan Pendidikan Karakter di Madrasah. Jurnal Pendidikan Islam, 3(1), 203-225. https://doi.org/10.14421/jpi.2014.31.203-225 
Sutarman, S., Tjahjono, H. K., \& Hamami, T. (2017). The Implementation of Holistic Education in Muhammadiyah's Madrasah Indonesia. Dinamika Ilmu, 17(2), 191-203. https://doi.org/10.21093/di.v17i2.856

Suyahmo. (2014). Filsafat pancasila. Magnum Pustaka Utama.

Tim Materi. (2017). Pedoman Perkaderan IPM Madrasah Muallimin Muhammadiyah Yogyakarta. PR IPM Muallimin.

Tim Penyusun. (2008). Sistem Perkaderan Muhammadiyah. In $M P K \quad P P$ Muhammadiyah. MPK PP Muhammadiyah.

Tim Penyusun. (2012). Buku Pedoman Pembinaan Siswa Madrasah Mu'allimin Muhammadiyah. In Buku Pedoman. Madrasah Mu'allimin Muhammadiyah.

Tull, A., Hirt, J. B., \& Saunders, S. (2009). Becoming Socialized in Student Affairs Administration: A Guide for New Professionals and Their Supervisors. VA: Stylus. https://www.amazon.com/Becoming-Socialized-Student-AffairsAdministration/dp/1579222765

Umami, I., Gani, A., \& Waskito, T. (2019). Proposal of character and moral education for gifted young scientists in Indonesia. Journal for the Education of Gifted Young Scientists, 7(2), 377-387. https://doi.org/10.17478/JEGYS.579560

Umar. (2015). Kebijakan Pengembangan Madrasah; Sebuah Wacana Strategi Reposisi. Al-Qalam; Jurnal Kajian Islam \& Kependidikan, 07(02), 125-149.

Wahyuni, A. (2017). Character Building in Islamic Boarding School (Case Study at Madrasah Mu'allimin Muhammadiyah Yogyakarta). Educational Research and Evaluation Yogyakarta State University, 21(1), 1-8.

Wangaard, B. D. (2016). Practices to Support Developing Academic Integrity in Secondary School Students. In Bretag T. (Ed.), Handbook of Academic Integrity. Springer, Singapore. https://doi.org/10.1007/978-981-287-098-8

Wasik, A. (2005). Pendidikan Islam di Asia Tenggara dan Asia Selatan: keragaman, permasalahan, dan strategi. RIDEP Institute-Friedrich Ebert Stiftung.

Widodo, H., Sutrisno, S., \& Hanum, F. (2019). The Urgency of Holistic Education in Muhammadiyah Schools. Al-Ta Lim Journal, 26(2), 160-174. https://doi.org/10.15548/jt.v26i2.549

Widodo, H. widodo. (2018). Implementation of Holistic Education in Muhammadiyah Elementary School Indonesia. International Journal for Innovation Education and Research, 6(9), 128-140. https://doi.org/10.31686/ijier.vol6.iss9.1162

Zhaoqin, Z. (1998). Moral Integrity Education in the Whole Moral Education [J]. Journal Of Shenzhen University (Humanities \& Social Sciences), 3. http://en.cnki.com.cn/Article en/CJFDTotal-SZDS803.013.htm 